\title{
A Crisis within a Crisis: COVID-19 Knowledge and Awareness among the Syrian Population-A National Survey Assessment
}

Fatema Mohsen ( $\square$ fatemamohsena@gmail.com )

Syrian Private University https://orcid.org/0000-0003-3472-6099

Batoul Bakkar

Syrian Private University Faculty of Medicine

Humam Armashi

Syrian Private University Faculty of Medicine

Nizar Aldaher

Syrian Private University Faculty of Medicine

Research article

Keywords: Awareness, Knowledge, COVID-19, Pandemic, Syria, War, Population

Posted Date: May 27th, 2020

DOI: https://doi.org/10.21203/rs.3.rs-28481/v1

License: (1) This work is licensed under a Creative Commons Attribution 4.0 International License. Read Full License 


\section{Abstract}

Background: COVID-19 is an infectious respiratory disease that emerged from a wet market in Wuhan China and quickly exploded into a global pandemic. This coronavirus has overwhelmed public health systems worldwide, and forced governments to impose draconian lockdowns of entire populations. With no vaccine or treatment to date, it is of paramount importance to assess the public's awareness about COVID-19 so that knowledge gaps among the population can be targeted with prevention-focused educational campaigns. The aim of this study is to examine the Syrian public's awareness and knowledge regarding COVID-19.

Methods: This web-based cross-sectional study was distributed randomly in March 2020, nearly 10 year into the Syrian war crisis. The survey consists of a series of questions about socio-demographic characteristics, knowledge of the causative agent, incubation period, treatment, transmission pathways, clinical features, and prevention methods. Data was analysed using the statistical Package for Social Sciences version 25.0 .

Results: Of the 3586 participants, $68.2 \%$ were females, $50.8 \%$ were unemployed, and $79.2 \%$ were at college-educated. The study revealed good awareness regarding COVID-19 (mean 75.6\%, SD $\pm 9.4 \%$ ). Multiple linear regression analysis correlated knowledge scores with gender, education level, occupation, economic status, and the number of household members.

Conclusion: This study revealed some potentially troubling knowledge gaps which underscore the need for a vigorous public education campaign. This campaign must reinforce the public's awareness, knowledge, and vigilance towards precautionary measures against COVID-19 and, most importantly aid in controlling the worldwide spread of the disease.

\section{Background}

Coronavirus disease 2019 (COVID-19), previously known as 2019 novel coronavirus disease, ${ }^{(1)}$ is a highly infectious respiratory disease that evolved into a worldwide pandemic threatening a prolonged economic recession. The first incidence was reported at a local seafood market in Wuhan, China (2). By April $20^{\text {th }}$ 2020, the virus had reached 214 different countries and territories and resulted in 3,517,345 cases and 243,401 deaths worldwide. ${ }^{(3)}$ On January $30^{\text {th }} 2020$, the World Health Organization (WHO) declared for the sixth time that COVID-19 outbreak is a public health emergency of international concern (PHEIC), prompting the organization to adopt and stipulate drastic global measures to stem the tide of the pandemic. $^{(4)}$

The battle against COVID-19 in Syria is still in its infancy. The first confirmed case was announced on March $22,{ }^{(5)}$ and there had only been 44 cases and 3 death to date. These figure are significantly lower than neighbouring countries such as Turkey $(127,659$ and 3,461), Iran (98,647 and 6,277), Iraq (2,346 and 98), Lebanon (740 and 25), and Jordan (465 and 9). ${ }^{(3)}$ The Syrian healthcare system is severely under- 
equipped and lacks the capacity to contain such a crisis. The estimated number of intensive care unit (ICU) beds with ventilators is mere 325 , and the theoretical maximum number of cases that can be adequately treated is only 6,500. ${ }^{(6)}$ Once this maximum threshold capacity is exceeded, drastic rationing decisions will have to be made. Therefore, cooperation with and response to guidance from the WHO are of utmost importance. Unprecedented measures have been adopted to control the spread of COVID-19 in Syria including: partial closure of borders; suspension of public transportation; closure of mosques, shops, parks, restaurants universities, and schools; isolation and care of suspected and infected individuals; curfews to limit social contact; and awareness campaigns. The public's adherence to these control measures- which is largely affected by their awareness, knowledge, and attitudes, towards COVID19 - is crucial to mitigating the further spread of the disease. ${ }^{(7,8)}$

The Syrian conflict, now in its $10^{\text {th }}$ year, has resulted in the worst refugee crisis since World War II. ${ }^{(9)}$ The devastating impact of war has placed the public health system under constant strain; the numbers of casualties continues to rise, $70 \%$ of health care workers have fled the country, the annihilation of healthcare facilities, and the "weaponization" of the healthcare are ongoing challenges. ${ }^{(6,10)}$ These challenges along with dense residential areas, the growing prevalence of chronic illness, and $83 \%$ of the population living under the poverty line make Syria highly vulnerable to a severe outbreak. $\left.{ }^{6}, 11\right)$

While some studies have been conducted to assess the knowledge, attitude, and practices among populations during this pandemic, none have done so in Syria. ${ }^{(12-19)}$ To our knowledge this first study that aims to measure the awareness and general knowledge of COVID-19 among the Syrian population at a time where ambiguity and misinformation are rampant. The objective of this study is to gauge specific knowledge around clinical features, transmission pathways, and prevention methods, and to identify factors associated with poor knowledge to help facilitate outbreak management in Syria during this rapid global rise of the COVID-19 pandemic.

\section{Methods}

\section{Study design, setting and participants}

This web-based cross-sectional survey was conducted between March $3^{\text {rd }}$ and April $4^{\text {th }}$. Ethical approval was obtained from the Institutional Review Board (IRB) of the Faculty of Medicine, Syrian Private University. All participants residing in Syria with no known history of COVID-19 infection were included in the study. The authors designed questions that were modelled after existing surveys. ${ }^{(12,13)}$ We conducted a pilot study on 20 people to assess clarity, relevance, and the acceptability of the survey; these were excluded from the final sample to avoid bias. Modifications were made based on feedback received to facilitate better comprehension before distributing the final survey to the general population. The Arabiclanguage survey was posted on various social media platforms including WhatsApp, Telegram, Instagram, and Facebook targeting various social groups. Participants confirmed their voluntarily participation by answering a yes-no question, were informed of the option to opt-out of the survey at any time, and were assured of the confidentiality and anonymity of their responses. After confirmation, 
participants were directed to the first part of the survey to complete questions about socio-demographic information including, age, gender, residence, education level, occupation, and economic status. Participants under the age of 18 required informed parental consent, as well as submission of parent/guardian contact information. The researchers were responsible for contacting the parents/guardians to obtain consent before the child was given access to the survey. The selfadministered survey contained 40 questions divided into 4 sections: general knowledge (10 questions), transmission pathways (7 questions), clinical features (12 questions), and prevention methods (11 questions). The survey is available in appendix 1.

\section{Statistical analysis}

Data was analyzed using the Statistical Package for Social Sciences version 25.0 (SPSS Inc., Chicago, IL, United States) and reported as frequencies and percentages (for categorical variables) or means and standard deviations (SD) (for continuous variables). One-way analysis of variance (ANOVA), t-test, or Chisquare test was applied to compare mean knowledge scores against socio-demographic variables. Multivariable linear regression analysis using the socio-demographic variables as independent variables and mean knowledge score as the outcome variable was conducted to identify factors associated with knowledge. P-values $<0.05$ was considered statistically significant.

\section{Results}

\section{Socio-demographics characteristics:}

Of 4495 total participants who completed the survey, 3942 were in Syria. 356 participants outside of Syria were excluded. The final sample of 3586 participants (completion rate=79.8\%) consisted of 2444(68.2\%) females and 1142(31.8\%) males. Participants aged 16-30 years were the majority $2789(77.8 \%)$ while participants under 16 were the minority 59(1.6\%). Participant ages ranged from 12-78 years with the majority being 19 (mean $=30 \pm 10$ years), single $2279(63.6 \%)$, and unemployed $1822(50.8 \%$ ). 1064(29.7\%) participants were smokers, and 428(11.9\%) were alcohol consumers (Table 1). The majority of participants were residents of Damascus/Rural Damascus 2019(56.3\%), and had attained college/university level education (Figure1).

\section{General Knowledge regarding COVID-19:}

Participants showed a good level of awareness regarding COVID-19 (75.6\%). An adequate level of basic knowledge (67.0\%) was found among participants (Table 2), 3383(94.3\%) knew that a virus was the causative agent of COVID-19; 2535(70.7\%) correctly identified the incubation period as being between 2 days and 2 weeks. Only 1500(41.8\%) knew that an infection with COVID-19 does not confer lifelong immunity. The majority of participants $3489(97.3 \%)$ were aware that COVID-19 infection in high risk groups can be fatal. There is currently insufficient evidence on whether infertility is a complication of COVID-19 infection; 461(12.9\%) participants believed that COVID-19 can cause infertility while 1903(53.0\%) did not. 2986(83.3\%), and 2597(72.4\%) correctly answered that there are currently no 
available vaccine or treatments; however, there were misconceptions about the efficacy of antibiotics and Ibuprofen as treatments, $1228(34.2 \%$ ) and $1268(35.3 \%)$ respectively (Table 3 ).

\section{Transmission and Signs and Symptoms regarding COVID-19:}

There was a fair level of awareness (70.7\%) regarding COVID-19 transmission pathways (Table 2). A high level of awareness was demonstrated regarding common transmission pathways: 3521(98.2\%), $3387(94.4 \%)$, and 3330(92.9\%) identified respiratory droplets, touching an infected person's personal belongings, and handshaking respectively. There is currently limited evidence on animal-to-human and sexual transmission; 703(19.6\%) did not know if transmission occurs between animals and humans, while $899(25.1 \%)$ did not know if the virus is transmitted sexually (Table 4).

The data showed a good level of awareness (76.0\%) regarding clinical features (Table 2). When asked about the main clinical features, participants correctly identified, fever 3563(99.4\%), sore throat $3037(84.7 \%)$, headache $3186(88.8 \%)$, chest pain 3050(85.0\%), general pain 3019(84.2\%), fatigue $3405(95.0 \%)$, and dry cough 3466(96.7\%), whereas only 1972(55.0\%) knew that diarrhea can be a symptom. Only 2221(61.9\%) were aware that infected individuals may be asymptomatic (Table 4).

\section{Prevention Methods regarding COVID-19:}

The highest level of awareness was in the prevention section (88.8\%) (Table 2). Washing hands with soap, avoiding crowded areas, remaining at home, and wearing a face mask outside are the principal preventative measures against COVID-19, 3574(99.7\%), 3574(99.75\%), 3554(99.1\%), and 3204(89.3\%), respectively. A minority $158(4.4 \%)$ believed that cleaning with a mixture of Flash and bleach is a sound preventive measure. Only 2482(69.2\%) knew that the flu vaccine offers no protection against COVID-19 (Table 5).

\section{Comparison Study:}

A series of one way ANOVA analyses revealed that mean knowledge differed significantly across: gender $(p$-value $=0.009)$ (Figure 2$)$, age ( $p$-value $=0.003)$, social status ( $p$-value $=0.042)$, education level $(p$ value $=0.000$ ), economic status ( $p$-value $=0.000)$, number of household members ( $p$-value $=0.000)$ (Table 4). The data showed a significant correlation between mean knowledge and place of residence ( $\mathrm{p}$ value $=0.000)$. Participants living in Lattakia $(77.6 \%)$ exhibited the greatest awareness, whereas those in Ar-Raqqah (71.7\%) followed by Deir-ez-Zor (71.8\%) exhibited the lowest (Figure 3).

Participants acquired their information from the following source(s): Social media, 1998(55.7\%); health websites, 2823(78.7\%); television/radio, 1572(43.8\%); family members/friends, 528(14.7\%); magazines/books, 266(7.4\%); and lectures, 517(14.4\%). Participants with the lowest awareness acquired their information from family members/friends (74.0\%), whereas those with the highest awareness acquired their information from lectures $(78.2 \%)$, ( $p$-value $=0.000)$, (Figure 4$)$. When participants were asked if they were likely to share new information with friends and family, 3513(98.0\%) answered "yes". There was a significant difference in mean knowledge between those who were inclined to disseminate 
new information about COVID-19 to friends and family (75.7\%) compared with those who were not $(72.3 \%)$ (p-value=0.002). On exclusive use of personal belongings, 2692(75.1\%) answered "yes". We found no significant correlation between mean knowledge and participant tendency to share personal belongings with others ( $p$-value=0.112). Participants who knew someone infected with COVID 19, 65(1.8\%) answered "yes". There was no significant difference in mean knowledge between those who knew an infected individual (75.9\%) compared with those who did not $(75.6 \%)(p$-value $=0.816)$.

\section{Multiple linear regression:}

Multiple linear regression analysis results: male gender (vs. female, $p=0.005$ ); education of secondary school or lower (vs. college/university and above, $p=0.000$ ); careers in government, private, business, military, and "other" sectors, as well as unemployment (vs. health care workers, $p=0.000$ ); poor and moderate economic status (vs. good and excellent, $p<0.040$ ), and over 5 household members (vs. of 1-5, $p=0.000$ ) were associated with significantly lower knowledge scores (Table 7). Careers in health care (vs. Unemployed, $p$-value $=0.000$ ), and the 31-45 age group (vs. 16-30, p-value $=0.005$ ) were associated with significantly higher knowledge scores.

\section{Discussion}

We found an overall mean knowledge score of $75.6 \%$, indicating that most participants were relatively knowledgeable about COVID-19, though less so compared to their counterparts in China (90\%). ${ }^{(12)}$ This level of knowledge was unexpected given that when we carried out the survey, only 10 cases of COVID-19 had been confirmed in Syria. ${ }^{(20)}$

We found that poor knowledge was associated with males, non-post-secondary education, nonhealthcare occupations, unemployment, poor and moderate economic status, and households exceeding 5 members (Table 5). Similar trends were observed in China. ${ }^{(12)}$ Correlating socio-demographic variables with awareness is critical to public health efforts to mitigate the spread of COVID-19. This data obtained can be leveraged by the Syrian Ministry of Health to tailor prevention and educational campaigns to populations with the widest knowledge gaps.

In the general knowledge section (67\%), the majority of the participants 3383(94.3\%) knew that COVID-19 is caused by a virus, similar to a Pakistani study (93.3\%). ${ }^{(17)}$ Low awareness of the 2 to 14 day incubation period was found, ${ }^{(21)}$ among dentists $(36.1 \%)$, and health care workers $(\mathrm{HCW})(36.4 \%) .(13,19)$ Our study showed a higher level of awareness 2535(70.7\%) among the population. Syria has a relatively young population; 2018 showed that only $4.5 \%$ of the population was over $65 .{ }^{(22)} 3489(97.3 \%)$ knew that COVID-19 infection can be severe and lead to death in elderly, chronically ill, and immunodeficient patients. This is higher than studies conducted in China (73.2\%), and India (88.37\%). ${ }^{(12,23)} 40.6 \%$ of Syrians are hypertensive, yet a staggering $79.8 \%$ of them are unaware of their condition. Diabetes is also prevalent, affecting $11.9 \%$ of the population. ${ }^{24,25)}$ Such a rampant lack of awareness about chronic disease in the population can be fatal, and underscores the need for targeted awareness campaigns. 
Only 2597(72.4\%) participants knew that there is currently no available treatment; this is higher than a Kenyan study (40\%) but significantly lower than a Chinese study $(94 \%) .{ }^{(12,15)}$ A minority $103(2.9 \%)$ participants thought there was a vaccine available against COVID-19; by contrast, Coimbatore District (18.6\%) and Pakistan (11.6\%) were misinformed. In the absence of a vaccine or effective treatment protocol for COVID-19, controlling the spread of the disease is the best line of defense. We observed a considerable knowledge gap in $1268(35.3 \%)$ with regards to ibuprofen as a treatment option. There is no available evidence to suggest that ibuprofen is effective against COVID-19.(26)

Participants showed a fair level of awareness regarding transmission pathways $(70.7 \%)$, very similar to a Pakistani study (70.8\%). ${ }^{(17)}$ The majority $3521(98.2 \%)$ of participants were aware that respiratory droplets are common transmission vectors this is similar to a Chinese study $(97.8 \%)$, but much higher than an Indian study $(29.5 \%){ }^{(12,16)}$ WHO advise on physical distancing include: using greetings that replace physical contact with a wave, nod, bow, peace sign, sign language, friendly words or smiles. ${ }^{(27,28)}$ $3330(92.9 \%)$ participants identified handshaking as a transmission pathway, higher than a study among dentists (85.6\%). ${ }^{(13)}$

A good level of awareness was found regarding the clinical features of COVID-19 (76.0\%), similar to a Pakistani (77.7\%). ${ }^{(17)}$ A very high level of awareness of the most common symptoms was found: fever $3563(99.4 \%)$, dry cough 3466(96.7\%), fatigue 3405(95.0\%), and myalgia 3019(84.2\%), similar to findings from Chinese $(96.4 \%)$ and Indian $(95.4 \%)$ studies. ${ }^{(12,23)}$ When asked about sore throat, a higher level of awareness $3037(84.7 \%)$ was found compared to studies from India (15.2\%) and among dentists (28.5\%). $(13,16)$ Knowledge about diarrhea as a symptom was lacking: only $1972(55.0 \%)$; a study among dentists also showed low awareness $(39.9 \%) .{ }^{(13,16)}$ While infected individuals are frequently asymptomatic, or present with mild symptoms, around 1 in every 5 infections can be serious enough to require hospitalisation. ${ }^{(4,29)}$ Only $2221(61.9 \%)$ participants were aware that infected individuals can be asymptomatic, while a study among dentists (34.5\%) reported much lower awareness. "Silent spreaders" may significantly contribute to the transmission of COVID-19, and so increasing public awareness of this particular point is crucial

We found a high level of awareness in the preventive methods section (88.8\%), similar to a study in Pakistan (85\%). ${ }^{(17)}$ Hand hygiene is considered an important element of infection control dating back to the revolutionary work of Ignaz Semmelweis. ${ }^{(30)}$ Implementing hand-washing techniques can break the transmission cycle and reduce the risk of infection by $6 \%-44 \%{ }^{(31)}$ Almost all $3574(99.7 \%)$ participants were aware that washing hands with soap and water is an important preventive measure against COVID19. This finding is in accordance with India (97.0\%), and other studies $(96.2 \%$, and $87 \%)$. ${ }^{(13,16,19)}$

This year the WHO recommended that the following mitigation measures be implemented during the holy month of Ramadan: cancelling social and religious gatherings, holding events outdoors for adequate ventilation, physical distancing of at least 1 meter between people, and the use of technology to broadcast ceremonies on television. ${ }^{(27,28)}$ The majority $3574(99.7 \%)$ identified avoiding mass gatherings 
as a preventive measure; studies in China (98.6\%) and Coimbatore District (97.7\%) reported similar awareness. ${ }^{(12,23)}$ Cheap and efficient interventions such as N95 (filtration capacity=95\%) have a $91 \%$ effectiveness of blocking pathogen transmission. ${ }^{(32)} 3204(89.3 \%)$ participants considered wearing a face mask when leaving home as an effective prevention method, compared with a Coimbatore District study $(93.02 \%){ }^{(23)}$

Since Syrian society is particularly vulnurable to COVID-19, this knowledge gap is potentially dangerous and should be addressed to mitigate disease spread. Only 2482(69.2\%) knew that the flu vaccine offers no protection against COVID-19; this is similar to a Coimbatore District study (67.4\%), but lower than a study amongst HCWs $(90.7 \%) .{ }^{(19,23)}$ Mixing flash with bleach is highly toxic and caustic to the respiratory tract. Only a minority of participants $158(4.4 \%)$ believed that this method of cleaning is a sound preventive measure. $3305(92.2 \%)$ were aware that individuals showing symptoms should quarantine themselves, lower than in China (98.2\%) and India (95.8\%). ${ }^{(12,16)}$

North-East Syria (NES) has a population of over 4 million people, 600,000 of whom are internally displaced refugees, 100,000 of whom live in overcrowded camps: only 2 of NES's 11 hospitals are currently functioning. NES consists of 3 governorates: Ar-Raqqah, Deir-ez-Zor and Al-Hasakah. With only 22 ICU beds, (18 in Al-Hasakah, 4 in Ar-Raqqah and none in Deir-ez-Zor), the maximum capacity threshold is only 80 COVID-19 cases. Ar-Raqqa and Deir-ez-Zor, the most vulnerable governorates, also showed the lowest awareness in the study $(71.7 \%)$, and $(71.8 \%)$. This is a potentially catastrophic situation, and a concern to the international community, as an unmonitored, uncontrolled outbreak in NES can prolong the global pandemic.

\section{Limitations}

Our findings can only be generalized about well-educated Syrians of good socio-economic status. Syrians vulnerable to COVID-19, such as the elderly and rural residents, are more likely to exhibit poor knowledge and awareness due to limited internet access. As such, reaching out to these populations must be prioritized. Even though all Syrian governorates were represented in this study, the majority of participants lived in Damascus and Rural Damascus. Furthermore, assessment of attitudes and practice towards COVID-19 is needed, which should be developed as either a web-based survey, or phone interviews, and constructed using multi-dimensional scaling.

\section{Conclusion}

COVID-19 has been a dire warning to humanity about the fragility of its social, economic, and healthcare institutions. Our study revealed good public awareness of clinical features and preventive measures. However general knowledge and knowledge about transmission pathways was suboptimal. Syrians of good socio-economic status, in particular young well-educated women, have shown good knowledge. Our national response must adapt to the growing threat of COVID-19 by adopting public awareness strategies and behaviours to contain the disease both within and beyond our borders. 


\section{Abbreviations}

COVID-19: Coronavirus Disease 2019; MERS: Middle East Respiratory Syndrome; SARS: Severe Acute Respiratory Syndrome; WHO: World Health Organization; PHEIC: Public Health Emergency of International Concern; ICU: Intensive care unit; IRB: Institutional Review Board; SPSS: Statistical Package for Social Sciences; SD: Standard Deviation; HCW: Health Care Worker.

\section{Declarations}

Acknowledgments:

We are thankful to the management of the Syrian Private University for the support in the field of medical training and research. We are thankful to everyone who participated in this study and for Mrs. Marah Muarrawi for her statistical help.

Funding:

Syrian Private University funded the study. No contribution to data design, collection, analysis, or interpretation was made by the funding resource. No other funding sources.

Availability of data and materials:

All data related to this paper's conclusion are available and stored by the authors. All data are available from the corresponding author on a reasonable request.

Ethics approval and consent to participate:

This study was approved by the Institutional Review Board (IRB) at the Syrian Private University (SPU). All Participants confirmed their written consent by answering a yes-no question. Participants under the age of 18 required verbal informed parental consent, as well as submission of parent/guardian contact information. The researchers were responsible for contacting the parents/guardians to obtain verbal consent before the child was given access to the survey. The verbal and written form of consent was approved by the IRB at SPU. Participation in the study was voluntary and participants were assured that anyone who was not inclined to participate or decided to withdraw after giving consent would not be victimized. All information collected from this study was kept strictly confidential.

Consent for Publication:

Not applicable.

Competing interests:

The authors declare that they have no competing interests. 
Authors' contributions:

FM conceptualized the study, participated in the design, wrote the study protocol, performed the statistical analysis, did a literature search and drafted the manuscript. BB participated in study design, did a literature search and drafted the manuscript. HA, and NA did a literature search, and revision of the draft. All authors read and approved the final draft.

\section{Tables}

Table 1. Socio-demographic characteristics: $(n=3586)$

\begin{tabular}{|c|c|c|c|c|c|}
\hline \multirow[t]{2}{*}{ Gender (\%) } & Male & 1142(31.8) & \multirow[t]{6}{*}{ Education (\%) } & Primary School & $25(0.7)$ \\
\hline & Female & $2444(68.2)$ & & $\begin{array}{l}\text { Intermediate } \\
\text { School }\end{array}$ & $166(4.6)$ \\
\hline \multirow[t]{4}{*}{ Age (\%) } & $<16$ & $59(1.6)$ & & Secondary school & $375(10.4)$ \\
\hline & $16-30$ & 2789(77.8) & & College/University & $2839(79.2)$ \\
\hline & $31-45$ & $503(14.0)$ & & Master's degree & $157(4.4)$ \\
\hline & $>45$ & 235(6.6) & & $\mathrm{PhD}$ & $24(0.7)$ \\
\hline \multirow{6}{*}{$\begin{array}{l}\text { Social } \\
\text { Status (\%) }\end{array}$} & Single & $2279(63.5)$ & \multirow[t]{7}{*}{ Occupation (\%) } & $\begin{array}{l}\text { Health care } \\
\text { worker }\end{array}$ & $634(17.7)$ \\
\hline & $\begin{array}{l}\text { In a } \\
\text { relationship }\end{array}$ & 286(8.0) & & $\begin{array}{l}\text { Government } \\
\text { institution }\end{array}$ & $283(7.9)$ \\
\hline & Married & $943(26.3)$ & & Private institution & 182(5.1) \\
\hline & Divorced & $46(1.3)$ & & Business & 198(5.5) \\
\hline & Widowed & $32(0.9)$ & & Military & $32(0.9)$ \\
\hline & & & & Unemployed & $1822(50.8)$ \\
\hline \multirow{4}{*}{$\begin{array}{l}\text { Economic } \\
\text { Status (\%) }\end{array}$} & ${ }^{1}$ Poor & $247(6.9)$ & & Other & $435(12.1)$ \\
\hline & ${ }^{2}$ Moderate & 1247(34.8) & \multirow[t]{3}{*}{$\begin{array}{l}\text { Household } \\
\text { members (\%) }\end{array}$} & 0 & $46(1.3)$ \\
\hline & ${ }^{3}$ Good & 1761(49.1) & & $1-5$ & $2751(76.7)$ \\
\hline & ${ }^{4}$ Excellent & $331(9.2)$ & & $>5$ & $789(22)$ \\
\hline
\end{tabular}

${ }^{1}$ Poor: income does not provide essential needs for the family. ${ }^{2}$ Moderate: income provides essential needs for the family but no more. ${ }^{3}$ Good: income provides essential needs and some luxury requirements. ${ }^{4}$ Excellent: income provides luxury requirements. 
Table 2. Mean knowledge score of participants by section

Mean Knowledge Score (\%) $\quad \pm$ Standard Deviation (\%)

\begin{tabular}{lll} 
General Knowledge & 67.0 & 18.9 \\
\hline Transmission Pathways & 70.7 & 16.9 \\
\hline Signs and Symptoms & 76.0 & 13.6 \\
\hline Prevention Methods & 88.8 & 10.2 \\
\hline Overall knowledge & 75.6 & 9.4
\end{tabular}


Table 3. General Knowledge around COVID-19: $(n=3586)$

\begin{tabular}{|c|c|c|c|c|c|c|c|}
\hline & Virus & Bacteria & Parasite & $\begin{array}{l}\text { Immune } \\
\text { deficiency }\end{array}$ & Fungus & Inherited & $\begin{array}{l}\text { Do Not } \\
\text { Know }\end{array}$ \\
\hline \multirow{3}{*}{$\begin{array}{l}\text { Causative } \\
\text { Agent N(\%) }\end{array}$} & 3383(94.3) & $39(1.1)$ & $8(0.2)$ & $46(1.3)$ & $0(0.0)$ & $2(0.1)$ & 108(3.0) \\
\hline & 1 Minute to & $\begin{array}{l}1 \text { Hour } \\
\text { to }\end{array}$ & \multirow{2}{*}{\multicolumn{2}{|c|}{2 Days to 2 Weeks }} & \multirow{2}{*}{\multicolumn{2}{|c|}{$\begin{array}{l}2 \text { Weeks to } 1 \\
\text { Month }\end{array}$}} & $\begin{array}{l}>1 \\
\text { Month }\end{array}$ \\
\hline & 1 חой & 2 Days & & & & & \\
\hline \multirow{2}{*}{$\begin{array}{l}\text { Incubation } \\
\text { period N(\%) }\end{array}$} & $18(0.5)$ & $58(1.6)$ & $2535(70.7)$ & & $958(26.7)$ & & $17(0.5)$ \\
\hline & & Yes(\%) & & No(\%) & & \multicolumn{2}{|c|}{ Do Not Know(\%) } \\
\hline \multicolumn{2}{|c|}{$\begin{array}{l}\text { Can infection with COVID-19 } \\
\text { confer permanent immunity? }\end{array}$} & $815(22.7)$ & & $1500(41.8)$ & & \multicolumn{2}{|c|}{$1271(35.5)$} \\
\hline \multicolumn{2}{|c|}{$\begin{array}{l}\text { Can COVID-19 cause severe } \\
\text { illness and lead to death in } \\
\text { elderly, chronically ill, and } \\
\text { immunodeficient patients? }\end{array}$} & \multicolumn{2}{|l|}{$3489(97.3)$} & $28(0.8)$ & & \multicolumn{2}{|l|}{$69(1.9)$} \\
\hline \multicolumn{2}{|c|}{$\begin{array}{l}\text { Can COVID-19 cause } \\
\text { infertility? }\end{array}$} & \multicolumn{2}{|l|}{$461(12.9)$} & $1222(34.1)$ & & \multicolumn{2}{|c|}{ 1903(53.0) } \\
\hline \multicolumn{2}{|c|}{$\begin{array}{l}\text { Is COVID-19 teratogenic (i.e. } \\
\text { cause } \\
\text { malformations/abnormalities } \\
\text { to an embryo/fetus)? }\end{array}$} & \multicolumn{2}{|l|}{$157(4.4)$} & $1433(40.0)$ & & \multicolumn{2}{|c|}{ 1996(55.6) } \\
\hline
\end{tabular}

\section{Treatment}

\begin{tabular}{llll}
\hline & Yes(\%) & No(\%) & Do Not Know(\%) \\
\hline $\begin{array}{l}\text { No treatment } \\
\text { available }\end{array}$ & $2597(72.4)$ & $515(14.4)$ & $474(13.2)$ \\
\hline Antibiotics & $1228(34.3)$ & $1790(49.9)$ & $568(15.8)$ \\
\hline Ibuprofen & $1268(35.3)$ & $1921(53.6)$ & $397(11.1)$ \\
\hline Vaccine & $103(2.9)$ & $2986(83.3)$ & $497(13.8)$
\end{tabular}


Table 4. Transmission, Signs, and Symptoms of COVID-19: $(n=3586)$

$\begin{array}{lll}\text { YES(\%) } & \text { NO(\%) } & \text { DO NOT } \\ & \text { KNOW(\%) }\end{array}$

\section{Transmission Pathways}

\begin{tabular}{|llll}
\hline Respiratory droplets (from coughing or sneezing) & $3521(98.2)$ & $21(0.6)$ & $44(1.2)$ \\
\hline Handshaking & $3330(92.9)$ & $189(5.3)$ & $67(1.8)$ \\
\hline Touching an infected person's personal belongings & $3387(94.4)$ & $131(3.7)$ & $68(1.9)$ \\
\hline Animals-to-human & $910(25.4)$ & $1973(55.0)$ & $703(19.6)$ \\
\hline Undercooked food & $1301(36.3)$ & $1734(48.3)$ & $551(15.4)$ \\
\hline Sexual contact & $1210(33.7)$ & $1477(41.2)$ & $899(25.1)$ \\
\hline Horizontal transmission & $1130(31.5)$ & $1160(32.4)$ & $1296(36.1)$ \\
\hline Signs and Symptoms & & & \\
\hline Fever & $3563(99.4)$ & $9(0.2)$ & $14(0.4)$ \\
\hline Sneezing & $2353(65.6)$ & $1000(27.9)$ & $233(6.5)$ \\
\hline Sore throat & $3037(84.7)$ & $358(10.0)$ & $191(5.3)$ \\
\hline Headache & $3186(88.8)$ & $190(5.3)$ & $210(5.9)$ \\
\hline Chest pain & $3050(85.0)$ & $254(7.1)$ & $282(7.9)$ \\
\hline Body aches (generalized pain) & $3019(84.2)$ & $260(7.2)$ & $307(8.6)$ \\
\hline Fatigue & $3405(95.0)$ & $72(2.0)$ & $109(3.0)$ \\
\hline Diarrhea & $1972(55.0)$ & $971(27.1)$ & $643(17.9)$ \\
\hline Dry cough & $3466(96.7)$ & $44(1.2)$ & $76(2.1)$ \\
\hline Productive cough & $458(12.8)$ & $2586(72.1)$ & $542(15.1)$ \\
\hline Bleeding & $130(3.6)$ & $2613(72.9)$ & $843(23.5)$ \\
\hline Asymptomatic & $2221(61.9)$ & $375(10.5)$ & $990(27.6)$ \\
\hline
\end{tabular}


Table 5. Prevention Methods: $(n=3586)$

\begin{tabular}{|c|c|c|c|}
\hline & YES(\%) & NO(\%) & $\begin{array}{l}\text { DO NOT } \\
\text { KNOW(\%) }\end{array}$ \\
\hline $\begin{array}{l}\text { Does wearing a face mask outside the home offer } \\
\text { protection from Covid-19? }\end{array}$ & $3204(89.3)$ & $314(8.8)$ & $68(1.9)$ \\
\hline $\begin{array}{l}\text { Does washing hands with soap and water offer protection } \\
\text { from Covid-19? }\end{array}$ & $3574(99.7)$ & $5(0.1)$ & $7(0.2)$ \\
\hline $\begin{array}{l}\text { Does avoiding crowded places offer protection from Covid- } \\
19 ?\end{array}$ & $3574(99.7)$ & $4(0.1)$ & $8(0.2)$ \\
\hline Does the flu vaccine offer protection from Covid-19? & $331(9.2)$ & 2482(69.2) & $773(21.6)$ \\
\hline Does staying at home offer protection from Covid-19? & $3554(99.1)$ & $15(0.4)$ & $17(0.5)$ \\
\hline Does using hand sanitizer offer protection from Covid-19? & $3430(95.6)$ & $104(2.9)$ & $52(1.5)$ \\
\hline $\begin{array}{l}\text { Does cleaning house items with bleach offer protection } \\
\text { from Covid-19? }\end{array}$ & $3408(95.0)$ & $110(3.1)$ & $68(1.9)$ \\
\hline $\begin{array}{l}\text { Does cleaning fruits and vegetables with soap and water } \\
\text { offer protection from Covid-19? }\end{array}$ & $3262(90.9)$ & $221(6.2)$ & $103(2.9)$ \\
\hline $\begin{array}{l}\text { Does cleaning surfaces with a mixture of Flash and bleach } \\
\text { offer protection from Covid-19? }\end{array}$ & $158(4.4)$ & $3301(92.1)$ & $127(3.5)$ \\
\hline $\begin{array}{l}\text { Does the quarantine of symptomatic individuals protect } \\
\text { others from Covid-19? }\end{array}$ & $3305(92.2)$ & $241(6.7)$ & $40(1.1)$ \\
\hline Do cumin, anise, and mint offer protection from Covid-19? & 1041(29.0) & 1934(53.9) & $611(17.1)$ \\
\hline
\end{tabular}


Table 6. Mean knowledge score of participants by demographic variables (one way ANOVA), ( $n=$ 3586)

\begin{tabular}{|c|c|c|c|c|c|}
\hline \multicolumn{2}{|l|}{ Characteristics } & \multirow{2}{*}{$\begin{array}{l}\begin{array}{l}\text { Number of } \\
\text { participants (\%) }\end{array} \\
1142(31.8)\end{array}$} & $\begin{array}{l}\text { Knowledge } \\
\text { Score (\%) }\end{array}$ & F-test & $\begin{array}{l}\mathrm{P}- \\
\text { value }\end{array}$ \\
\hline \multirow[t]{2}{*}{ Gender } & Male & & 75.0 & \multirow[t]{2}{*}{-2.625} & \multirow[t]{2}{*}{$0.009 *$} \\
\hline & Female & 2444(68.2) & 75.9 & & \\
\hline \multirow{4}{*}{$\begin{array}{l}\text { Age-group } \\
\text { (years) }\end{array}$} & $<16$ & $59(1.6)$ & 71.5 & \multirow[t]{4}{*}{4.770} & \multirow[t]{4}{*}{$0.003^{*}$} \\
\hline & $16-30$ & 2789(77.8) & 75.8 & & \\
\hline & $31-45$ & $503(14.0)$ & 75.7 & & \\
\hline & $>45$ & $23(6.6)$ & 74.8 & & \\
\hline \multirow[t]{5}{*}{ Social status } & Single & 2279(63.5) & 75.8 & \multirow[t]{5}{*}{2.485} & \multirow[t]{5}{*}{$0.042 *$} \\
\hline & In a relationship & 286(8.0) & 76.6 & & \\
\hline & Married & $943(26.3)$ & 75.1 & & \\
\hline & Divorced & $46(1.3)$ & 73.9 & & \\
\hline & Widowed & $32(0.9)$ & 73.4 & & \\
\hline \multirow[t]{2}{*}{ Residence } & Urban & 2426(67.7) & 75.8 & \multirow[t]{2}{*}{1.652} & \multirow[t]{2}{*}{0.099} \\
\hline & Rural & $1160(32.3)$ & 75.3 & & \\
\hline \multirow[t]{6}{*}{ Education } & Primary school & $25(0.7)$ & 66.5 & \multirow[t]{6}{*}{26.176} & \multirow[t]{6}{*}{$0.000 *$} \\
\hline & Intermediate school & $166(4.6)$ & 73.2 & & \\
\hline & Secondary school & $375(10.4)$ & 70.0 & & \\
\hline & College/University & 2839(79.2) & 76.3 & & \\
\hline & Master's degree & $157(4.4)$ & 77.2 & & \\
\hline & $\mathrm{PhD}$ & $24(0.7)$ & 76.6 & & \\
\hline \multirow[t]{3}{*}{ Occupation } & Health care worker & $634(17.7)$ & 78.6 & \multirow[t]{3}{*}{16.379} & \multirow[t]{3}{*}{$0.000 *$} \\
\hline & $\begin{array}{l}\text { Government } \\
\text { institution }\end{array}$ & $283(7.9)$ & 75.7 & & \\
\hline & Private institution & 182(5.1) & 75.5 & & \\
\hline
\end{tabular}


$\begin{array}{lll}\text { Business } & \text { 198(5.5) }\end{array}$

\begin{tabular}{lll}
\hline Military & $32(0.9)$ & 71.2 \\
\hline Unemployed & $1822(50.8)$ & 75.3
\end{tabular}

\begin{tabular}{|c|c|c|c|c|c|}
\hline & & & & & \\
\hline & Other & $435(12.1)$ & 74.0 & & \\
\hline \multirow[t]{4}{*}{ Economic status } & Excellent & $331(9.2)$ & 76.6 & \multirow[t]{4}{*}{7.108} & \multirow[t]{4}{*}{0.000 * } \\
\hline & Good & $1761(49.1)$ & 76.2 & & \\
\hline & Moderate & $1247(34.8)$ & 74.9 & & \\
\hline & Poor & $247(6.9)$ & 74.3 & & \\
\hline \multirow{3}{*}{$\begin{array}{l}\text { Household } \\
\text { members }\end{array}$} & 0 & $46(1.3)$ & 74.4 & \multirow[t]{3}{*}{15.451} & \multirow[t]{3}{*}{$0.000 *$} \\
\hline & $1-5$ & $2751(76.7)$ & 76.1 & & \\
\hline & $>5$ & $789(22.0)$ & 74.0 & & \\
\hline
\end{tabular}

Table 7. Multiple linear regression on variables associated with poor COVID-19 knowledge

\begin{tabular}{|c|c|c|c|c|}
\hline Standard error & $\mathrm{t}$ & $\mathbf{P}$ & & \\
\hline Gender (male vs. female) & -0.933 & 0.334 & -2.794 & $0.005^{\star}$ \\
\hline $\begin{array}{l}\text { Education (primary, intermediate, secondary school vs. } \\
\text { college/university, master, PhD) }\end{array}$ & -3.782 & 0.466 & -8.125 & $0.000 *$ \\
\hline $\begin{array}{l}\text { Occupation (government, private sector, business, military, } \\
\text { unemployed, other vs. health care worker) }\end{array}$ & -3.592 & 0.474 & -7.579 & $0.000 *$ \\
\hline Economic status (moderate, poor vs. excellent, good) & -0.669 & 0.325 & -2.057 & $0.040 *$ \\
\hline Household members(>5 vs. $1-5)$ & -1.737 & 0.374 & -4.648 & $0.000 *$ \\
\hline
\end{tabular}

\section{References}

1. Naming the coronavirus disease (COVID-19) and the virus that causes it. World Health Organization. 2020.

2. Huang C, Wang Y, Li X, Ren L, Zhao J, Hu Y, et al. Clinical features of patients infected with 2019 novel coronavirus in Wuhan, China. The Lancet. 2020;395(10223):497-506.

3. Organization WH. Coronavirus disease 2019 (COVID-19): situation report, 106. 2020. 
4. Organization WH. Getting your workplace ready for COVID-19: How COVID-19 spreads, 19 March 2020. World Health Organization; 2020.

5. McKernan B. Syria confirms first Covid-19 case amid fears of catastrophic spread. The Guardian. 2020.

6. Gharibah M, Mehchy Z. COVID-19 pandemic: Syria's response and healthcare capacity. 2020.

7. Ajilore K, Atakiti I, Onyenankeya K. College students' knowledge, attitudes and adherence to public service announcements on Ebola in Nigeria: Suggestions for improving future Ebola prevention education programmes. Health Education Journal. 2017;76(6):648-60.

8. Tachfouti N, Slama K, Berraho M, Nejjari C. The impact of knowledge and attitudes on adherence to tuberculosis treatment: a case-control study in a Moroccan region. Pan African Medical Journal. 2012;12(1).

9. McNatt Z, Boothby NG, Al-Shannaq H, Chandler H, Freels P, Mahmoud AS, et al. Impact of Separation on Refugee Families: Syrian Refugees in Jordan. 2018.

10. Syria anniversary press release. United Nations Office for the Coordination of Humanitarian Affairs (OCHA). 2020.

11. UNICEF Syria Crisis Situation Report 2019.

12. Zhong B-L, Luo W, Li H-M, Zhang Q-Q, Liu X-G, Li W-T, et al. Knowledge, attitudes, and practices towards COVID-19 among Chinese residents during the rapid rise period of the COVID-19 outbreak: a quick online cross-sectional survey. International Journal of Biological Sciences. 2020;16(10):1745.

13. Khader Y, Al Nsour M, Al-Batayneh OB, Saadeh R, Bashier H, Alfaqih M, et al. Dentists' Awareness, Perception, and Attitude Regarding COVID-19 and Infection Control: Cross-Sectional Study Among Jordanian Dentists. JMIR Public Health and Surveillance. 2020;6(2):e18798.

14. Qarawi A, Ng SJ, Gad A, Luu M, Al-Ahdal T, Sharma A, et al. Awareness and Preparedness of Hospital Staff against Novel Coronavirus (COVID-2019): A Global Survey - Study Protocol. SSRN Electronic Journal. 2020.

15. Austrian K, Pinchoff J, Tidwell JB, White C, Abuya T, Kangwana B, et al. COVID-19 related knowledge, attitudes, practices and needs of households in informal settlements in Nairobi, Kenya. 2020.

16. Roy D, Tripathy S, Kar SK, Sharma N, Verma SK, Kaushal V. Study of knowledge, attitude, anxiety \& perceived mental healthcare need in Indian population during COVID-19 pandemic. Asian Journal of Psychiatry. 2020:102083.

17. Hussain T, Khan S, Gilani U, Raza S. Evaluation of General Awareness Among Professionals Regarding COVID-19: A Survey Based Study from Pakistan. 2020.

18. Zhou M, Tang F, Wang Y, Nie H, Zhang L, You G, et al. Knowledge, attitude and practice regarding COVID-19 among health care workers in Henan, China. Journal of Hospital Infection. 2020.

19. Bhagavathula AS, Aldhaleei WA, Rahmani J, Mahabadi MA, Bandari DK. Novel Coronavirus (COVID19) Knowledge and Perceptions: A Survey on Healthcare workers. medRxiv. 2020.

20. Organization WH. Coronavirus disease 2019 (COVID-19): situation report, 71. 2020. 
21. Backer J, Klinkenberg D, Wallinga J. Incubation period of 2019 novel coronavirus (2019-nCoV) infections among travellers from Wuhan, China, 20-28 January 2020. Eurosurveillance. 2020;25.

22. Plecher H. Age structure in Syria 2018. Statista. 2020.

23. Vadivu TS, Annamuthu P. An Awareness and Perception of COVID-19 among General Public-A Cross Sectional Analysis. 2014.

24. Organization WH. Web World Health Organization-Diabetes country profiles. Diakses; 2016.

25. Tailakh A, Evangelista LS, Mentes JC, Pike NA, Phillips LR, Morisky DE. Hypertension prevalence, awareness, and control in A rab countries: A systematic review. Nursing \& health sciences. 2014;16(1):126-30.

26. The use of non-steroidal anti-inflammatory drugs (NSAIDs) in patients with COVID-19. World Health Organization. 2020.

27. Practical considerations and recommendations for religious leaders and faith-based communities in the context of COVID-19. World Health Organization. 2020.

28. Safe Ramadan practices in the context of the COVID-19 World Health Organization. 2020.

29. Surveillances V. The epidemiological characteristics of an outbreak of 2019 novel coronavirus diseases (COVID-19) -China, 2020. China CDC Weekly. 2020;2(8):113-22.

30. Best M, Neuhauser D. Ignaz Semmelweis and the birth of infection control. Quality \& safety in health care. 2004;13:233-4.

31. Rabie T, Curtis V. Handwashing and Risk of Respiratory Infections: A Quantitative Systematic Review. Tropical medicine \& international health : TM \& IH. 2006;11:258-67.

32. Jefferson T, Foxlee R, Del Mar C, Dooley L, Ferroni E, Hewak B, et al. Physical interventions to interrupt or reduce the spread of respiratory viruses: systematic review. Bmj. 2008;336(7635):77-80.

\section{Figures}




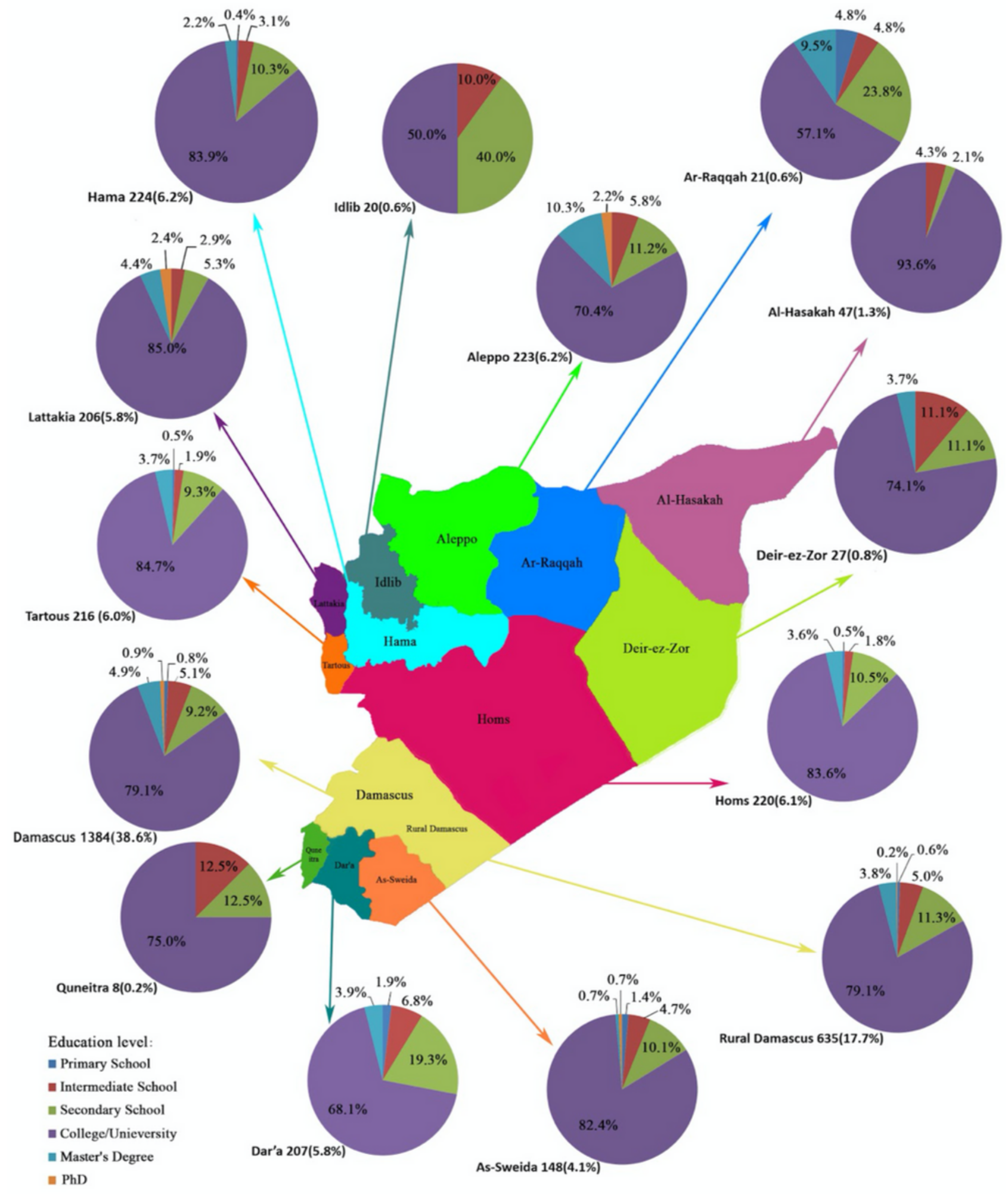

\section{Figure 1}

Distribution of participants according to governorates and education level 


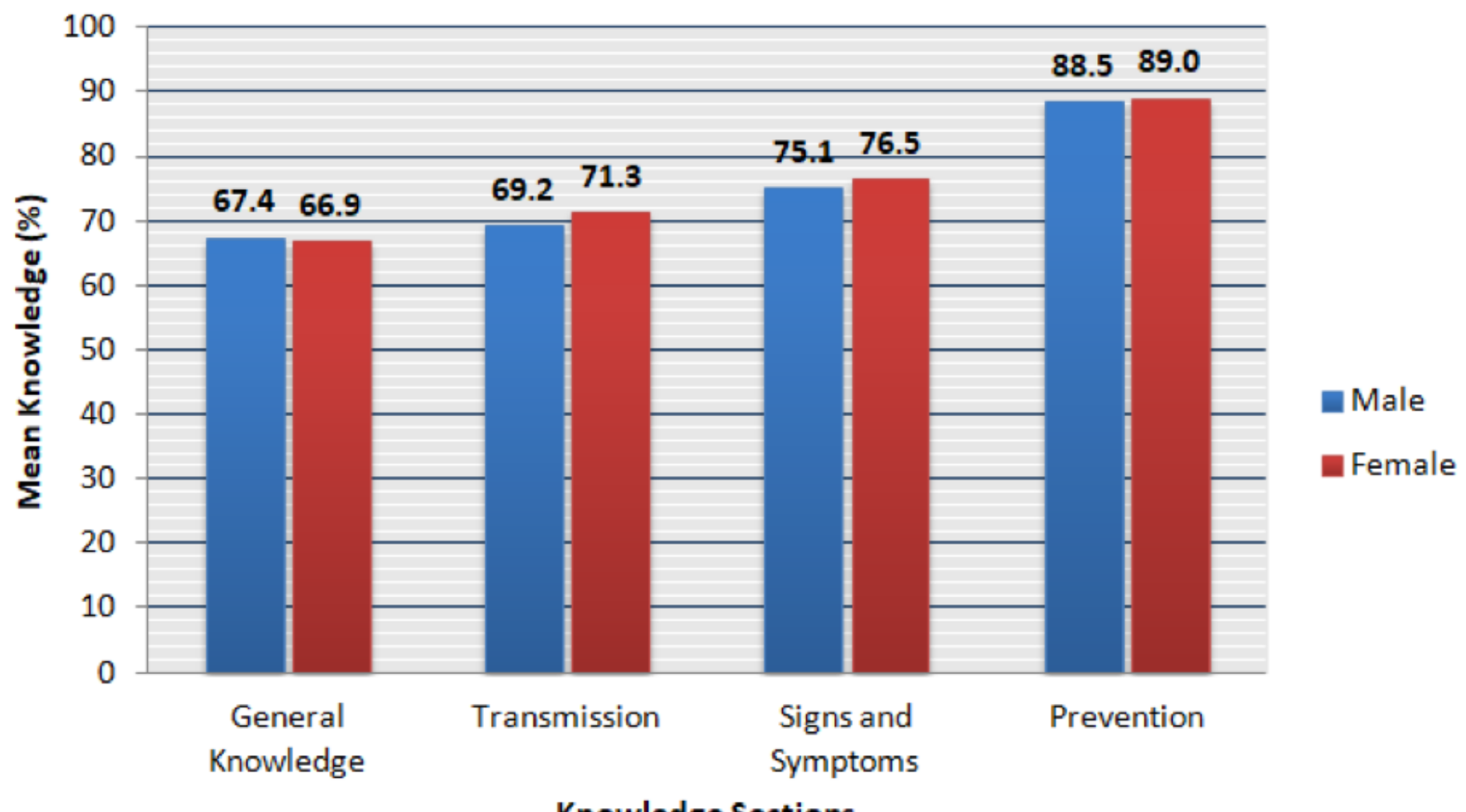

Figure 2

Relationships between both genders and mean knowledge. 
- Overall Knowledge $\square$ General knowledge $\square$ Transmission $\square$ Signs and Symptoms $\square$ Prevention

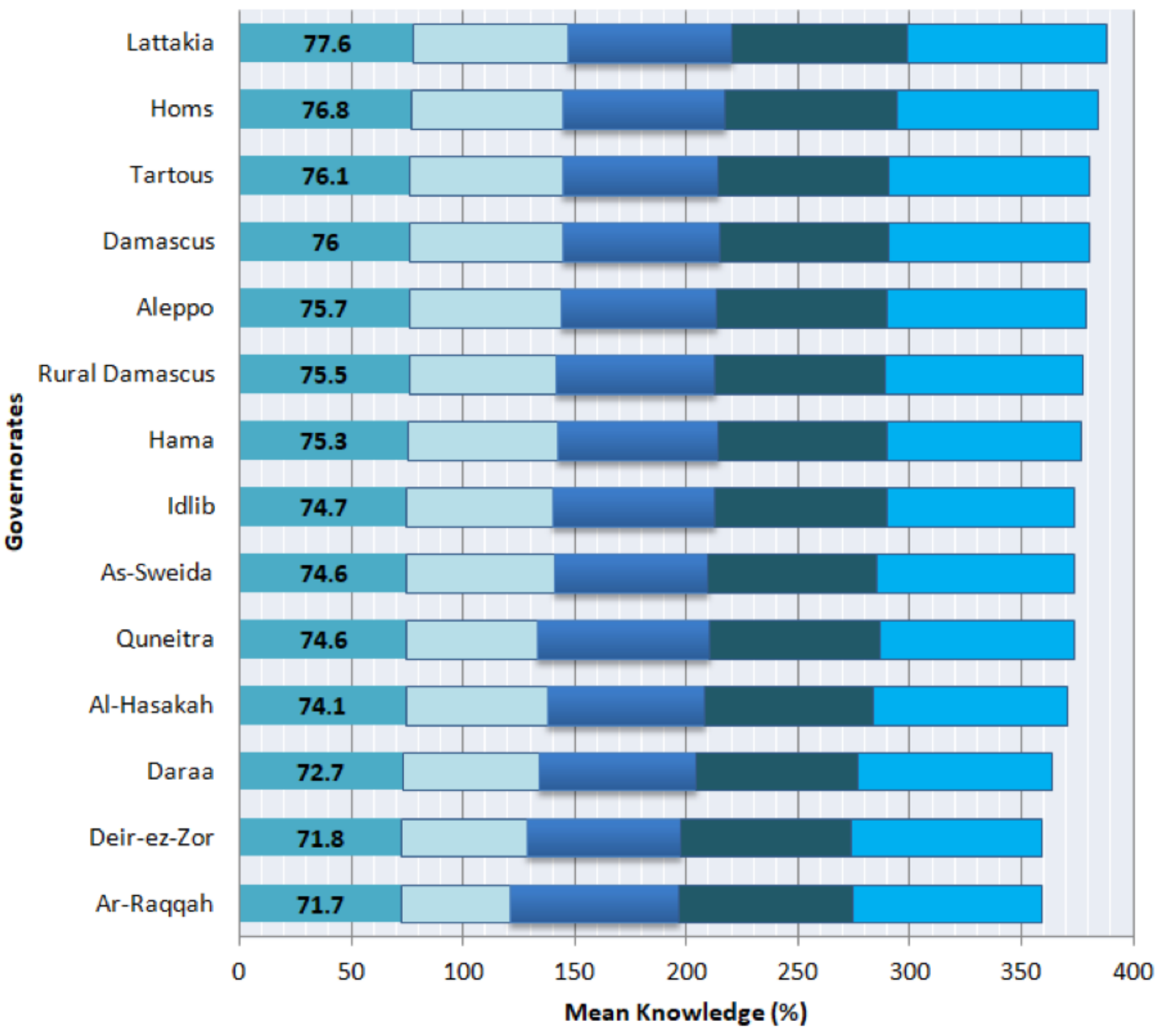

Figure 3

Relationship between place of residence and mean knowledge. 


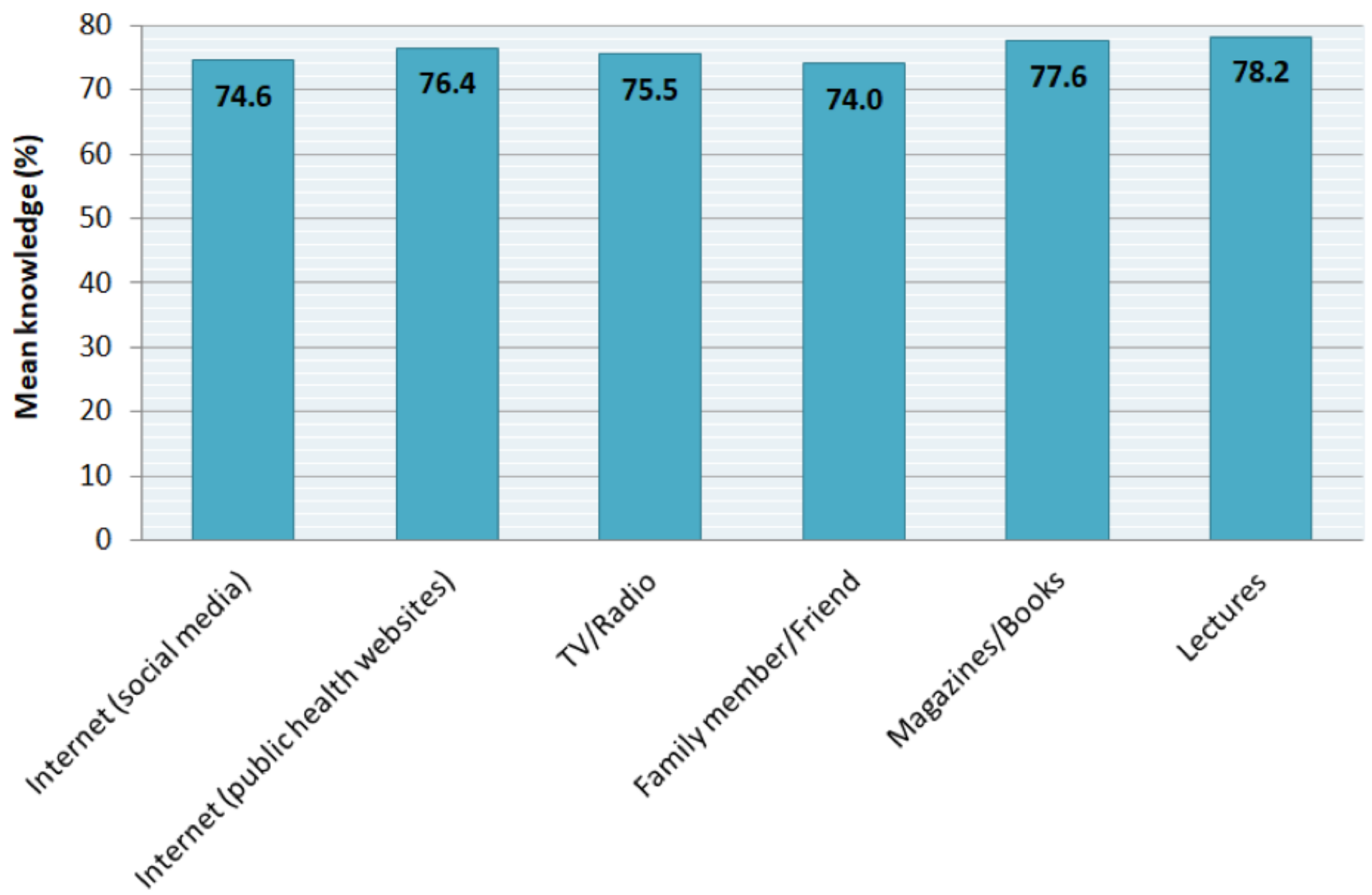

Source(s) of information

Figure 4

The relationship between different sources of information and mean knowledge.

\section{Supplementary Files}

This is a list of supplementary files associated with this preprint. Click to download.

- Appendix1.docx 